\title{
'It Would Be Silly to Stop Now and Go Part-Time': Fathers and Flexible Working Arrangements in Australia
}

\author{
Ashlee Borgkvist
}

\section{Introduction}

The rates of men taking up formal flexible working arrangements in Australia, including parental leave, are relatively low when compared to women in Australia and when compared with men in other countries (Baxter 2013; Craig and Mullan 2010; Huerta et al. 2013). Flexible working arrangements, sometimes referred to as flexibility, are generally understood to be any working arrangements where the employee has some influence over where, when, how much, and how work is conducted (Williams 2010). Some barriers that impact men's use of flexible working arrangements include: a lack of support from managers and co-workers; career consequences such as missing out on promotions and pay raises; organizations' expectations in relation to men's use of flexibility; and the ideal worker norm (Acker 1990; Kelly et al. 2010). Investigating men's use of flexible working arrangements in Australia revealed a strong link between masculine identity and paid work. The importance of masculine identity among Australian men impacted decisions regarding work, family, and the uptake of flexible working arrangements (see Borgkvist et al. 2018).

In this chapter I present findings from semi-structured interviews with 15 working fathers in South Australia (see Table 1 for descriptive statistics). I discuss the link between masculinity, fathering, paid work, and men's uptake of flexibility. I further discuss the reciprocal influence of these factors on the development of Australian family policy, and some of the broader implications for policy and practice.

\footnotetext{
A. Borgkvist $(\bowtie)$

Safe Relationships and Communities Research Group, The University of South Australia, Adelaide, SA, Australia

e-mail: ashlee.borgkvist@unisa.edu.au 
Table 1 Participant information

\begin{tabular}{cl|l|l|l|l|l}
\hline $\begin{array}{l}\text { Participant \#I } \\
\text { Pseudonym }\end{array}$ & Age & Occupation & $\begin{array}{l}\text { Relationship } \\
\text { Status }\end{array}$ & $\begin{array}{l}\text { Number/Age } \\
\text { of children }\end{array}$ & $\begin{array}{l}\text { Flexible Working } \\
\text { Arrangement }\end{array}$ \\
\hline 1. $\quad$ Mike & 40 & Program officer & Married & $2 / 6,4$ & No \\
\hline 2. & Mark & 38 & Call Centre & Married & $3 / 5,3,0.5$ & Informal \\
\hline 3. $\quad$ Carl & 33 & $\begin{array}{l}\text { Administration } \\
\text { officer }\end{array}$ & Married & $1 / 3,1$ on way & No \\
\hline 4. $\quad$ David & 45 & $\begin{array}{l}\text { Community } \\
\text { planner }\end{array}$ & Married & $3 / 10,8,3$ & Informal \\
\hline 5. & Ernie & 52 & $\begin{array}{l}\text { Community } \\
\text { planner }\end{array}$ & Married & $2 / 16,12$ & Informal \\
\hline 6. & Frank & 43 & Journalist & Married & $2 / 9,6$ & No \\
\hline 7. & Gary & 33 & $\begin{array}{l}\text { Financial } \\
\text { manager }\end{array}$ & Married & $2 / 8,6$ & No \\
\hline 8. & Harry & 39 & Senior lecturer & Married & $3 / 10,8,3$ & No \\
\hline 9. $\quad$ Jerry & 46 & IT consultant & Married & $3 / 21,19,7$ & No \\
\hline 10. $\quad$ Kieran & 39 & Communications & Married & $\begin{array}{l}2 / 2,4,1 \text { on } \\
\text { way }\end{array}$ & $\begin{array}{l}\text { Part time }-4 \text { days } \\
\text { per week }\end{array}$ \\
\hline 11. & Larry & 36 & Researcher & Married & $2 / 5,3$ & $\begin{array}{l}\text { Part time }-4 \text { days } \\
\text { per week }\end{array}$ \\
\hline 12. & Nick & 42 & Team leader & Married & $2 / 8,6$ & No \\
\hline 13. & Oscar & 41 & $\begin{array}{l}\text { Administration } \\
\text { officer }\end{array}$ & Married & $1 / 2$ & $\begin{array}{l}\text { Part time }-4 \text { days } \\
\text { per week }\end{array}$ \\
\hline 14. & Phil & 51 & Social worker & Married & $3 / 17,14,17 \mathrm{~m}$ & No \\
\hline 15. & Ross & 46 & $\begin{array}{l}\text { Scientist/ } \\
\text { manager }\end{array}$ & De facto & $4 / 15,13,4,3$ & No \\
\hline
\end{tabular}

\section{The Link Between Masculinity, Fathering, and Paid Work}

Expectations of fathers and some fathering practices have changed over time (Miller 2017). The past few decades have seen changes in father's expressed desires to be involved, and expectations that fathers will be more involved in all aspects of child rearing (Dolan and Coe 2011; Miller 2017; O'Brien et al. 2007; Suwada 2017). These changing expectations likely reflect the complex and evolving nature of society and of what is considered good or normative fathering at different times.

The concept of hegemonic masculinity (Connell 2005b) suggests that within societies and cultures there is a dominant idea of what it is to be masculine, and the achievement of this kind of masculinity impacts the way fathering is performed (Coltrane et al. 2013; Shirani et al. 2012; Suwada 2017). In other words, to legitimise their status as both fathers and men, men are influenced to perform fathering in certain ways. These performances have traditionally included financial provision and engagement with paid work - almost to the exclusion of engagement with activities within the home, which has been considered more suitable for women (Connell 2005a; Pedulla and Thébaud 2015). Some research has found that men still associate 
manhood with having a job (Edley and Wetherell 1999; Shirani et al. 2012), and being a father with being able to financially provide for their family and children (Brandth and Kvande 2002; Harrington et al. 2010).

Further, the link between masculinity, fathering, and paid work influences what actions men feel are acceptable in the workplace - including taking periods of leave and using flexibility for family reasons (Brandth and Kvande 1998; Coltrane et al. 2013; Kelly et al. 2010). Men perceiving a need to work in a way which shows their dedication to paid work can be explained by a concept called the ideal worker norm, which was first proposed by Joan Acker (1990). The concept refers to the idea that the ideal worker is someone who is dedicated to work with no outside distractions, including family. This has historically been the male worker because their female partners have been held responsible for the private sphere of the home and for children. The concept of the ideal worker norm continues to have a large influence on the ways in which men perform work, because 'living up to the ideal worker norm is an important way to enact masculinity - and protect a privileged position' (Kelly et al. 2010:283; see also Cooper 2000) both in the workplace and at home. Organizational cultures are affected by what occurs outside of them in society and wider culture (Acker 1990). The association between paid work, masculine identity, and fathering which exists culturally also exists within organizations, and men are encouraged to behave in ways consistent with the provider role - within as well as outside of organizations.

The fathering role has historically been associated with different things than the mothering role - authoritarianism and breadwinning rather than emotion and caring (Halford 2006). These cultural divisions have different practical consequences. Research in the United States, for example, found that some fathers have 'difficulty seeing themselves in the role of stay-at-home spouse and primary caregiver. Part of this derived from their own sense of career identity' (Harrington et al. 2010:20; see also his chapter this volume for further discussion). In this research, fathers reported a strong connection between their careers and their identities. Many stated that:

\footnotetext{
'being a stay at home spouse did not fit with their views of themselves as a primary breadwinner. Equally important was the feeling that for a man to choose this option might be seen as not living up to his financial provider role in the eyes of others.' (p. 20).
}

A historical reliance on, and expectation of, women to conduct care work and on men to perform the role of the ideal worker and financially provide, can therefore be seen not only to be prescriptive for women but to restrict men's abilities to deviate from gendered expectations as well (see Correll et al. 2014). Men's use of flexible working arrangements for family reasons can be seen as transgressing the normal role they are expected to inhabit in an organization and within families. 


\section{Fathering and Paid Work in Australia}

The association between paid work and fathering identity is important in the Australian context because of the special expression of masculinity in Australia. The historical influences on the formation and performance of masculinity in Australia will be explored briefly here to contextualise the findings presented later in this chapter.

Australian researcher and academic Raewyn Connell noted that masculinity expectations in Australia encourage men to behave in certain socially and culturally specific ways (Connell 2005a, b, 2014). Mateship - a kind of social contract in which men are expected to support other men who display appropriate and accepted masculinity - is something perceived as a core aspect of Australian masculinity. Connell has argued that mateship specifically has had a large influence on how Australian men interact with one another, and the social and cultural expectations of Australian men (see also Murrie 1998).

Masculine identity in Australia and mateship stems from historical legends that came to represent archetypal masculinity. Australia is a colonial society with a convict history. Manual labour, physical strength, stoicism, and endurance came to be culturally valued and revered (Dyrenfurth 2015; Summers 1975). Mateship grew out of these conditions, and can be seen to rest on the same kind of tenants as Connell's (2005a) conception of a dominant or hegemonic form of masculinity. This dominant form of masculinity involves the inclusion of accepted and revered masculine behaviours and the exclusion of what is considered feminine behaviour, in order to uphold a gender structure which privileges the masculine. This means a focus on what Australian men do rather than what they might feel (Connell 2014).

Thus, the performance of Australian masculinity has come to be heavily reliant on what men are able to achieve in the public sphere - that is, through engagement with and in paid work. Australian masculinity, then, is in part maintained by the dedication of Australian men to financial provision within families. Stepping away from full-time paid work in order to engage more fully in caregiving could therefore be viewed in opposition to what it means to be masculine in Australia.

\section{The Development of Policy in Australia}

The development and progression of Australian legislation in relation to family life and parenting has had a large impact on Australian masculinity, in part by making explicit the roles that Australian men and women should play within the family unit (Brennan 2011). Parenting roles in Australia have arguably been 'configured in relation to pro-natalist discourses and policies which shape maternal and paternal domains'. Historically, these have '... [had] a central focus on women as mother, reinforcing binary dimensions' (Miller and Nash 2016:2). The masculinist history surrounding Australian families and the development of family policies such as the 
Family Tax Benefit and Paid Parental Leave within this culture, reinforced the breadwinner/caregiver dichotomy. Subsequently, the development of a particular kind of masculine and fathering identity in the Australian culture was encouraged and reinforced.

Australia lacked a national system of Paid Parental Leave (PPL) until 2011, despite previous efforts to create one (Pocock et al. 2013). The delay has been argued to have 'largely reflected three things: a strongly masculinist general culture; the dominance of a "male breadwinner" model of the worker; and the absence of a contributory insurance-based system of workplace benefits' (Pocock et al. 2013:599). The historically difficult nature of employees' access to paid leave and access to flexibility (Charlesworth and Heron 2012; Pocock et al. 2013), and the patriarchal social climate of Australia (Connell 2014; Miller and Nash 2016; Summers 1975) has meant that a reliance on gendered patterns, particularly the male breadwinner model, has been etched into Australian families' work and care arrangements.

The male breadwinner model, and the focus on altering women's ways of working but not men's, is reflected in the government-funded parental leave policies currently available to mothers and fathers in Australia. The Australian Governmentfunded PPL scheme offers 18 weeks leave to the primary carer, paid at minimum wage. In 2013, Dad and Partner Pay (DPP) was introduced for secondary carers, to be taken at the same time as the primary carer, and again paid at the minimum wage. Employers can also offer their own paid parental leave should they choose, although not all do.

While the PPL scheme for primary carers is gender neutral, these parental leave policies facilitate women taking time off from work to care while not providing adequate support for fathers to do the same (see, for example, Brandth and Kvande 2018). The primary carer for the first 18 weeks of a child's life is much more likely to be a woman, in part because women need to physically recover after giving birth and also may choose to breastfeed, and in part because women are likely to earn less than their male partners. Women are consequently much more likely to take the whole 18 weeks of paid leave, and this is reflected in the very low numbers of Australian men who utilise any PPL - approximately 2-3\% (OECD 2016). Further, if a father's employer does not offer paid secondary carer's leave, they are put in the position of taking unpaid leave or using annual or personal leave if they want to take more than 2 weeks off from work when their child is born.

With a focus on increasing father's use of parental leave for the past 40 years, Sweden in particular has seen a large increase in fathers using parental leave and flexible working arrangements after the birth of children as a result of policy change. This has come to be an accepted and expected norm (see Suwada 2017). Due to the way it is set up, Australia's current PPL and DPP scheme essentially encourages one carer to be at home providing care - and this is usually the mother. Further, taking unpaid leave, or even leave paid at minimum wage, is often not enough to support families financially. Compared with most Scandinavian countries where men receive numerous months of paid parental leave under a 'use it or lose it' policy (OECD 2016), Australia’s family policies seem conservative. 


\section{Men's Uptake of Flexible Working Arrangements in Australia}

In Australia, evolving fathering expectations, and the seeming recognition of these expectations by Australian fathers, has seen them reporting an increase in care activities (see Baxter 2013; Baxter and Smart 2011). This increase in performing caregiving tasks points to a possible renegotiation and expansion of Australian masculinity. However, despite this increase in involvement, research has found that mothers are still primarily held responsible for care and for the emotional and mental work associated with this care, such as co-ordinating when and how fathers engage in caregiving and other unpaid labour (Singleton and Maher 2004; Riggs and Bartholomaeus 2018). Recent research also found that fathers thought they were not helpful to infants and would not be helpful at home after the birth of their children (Rose et al. 2015; Borgkvist et al. 2018).

Australian men have been found to express a need to increase their work hours when their children are born, which can be seen as an enactment of fathering identity linked to breadwinning (Gray 2013). On the other hand, Australian women decrease their involvement with paid work after children are born (Baxter and Hewitt 2013). A multitude of research shows that after the birth of a child, traditional gender roles become more delineated in relationships, and specifically 'in the Australian context fathers widen the gender gap by extending their paid work time upon becoming a father' (Gray 2013:172).

Though it appears that Australian men are engaging in relatively more caregiving behaviours than in the past, women are still held responsible for the majority of caregiving. This gendered dynamic is not specific to Australia (Miller 2011; Suwada 2017), however the distinct nature of Australian masculinities helps us to understand the association between fathering and paid work, and the barriers in utilising flexible working arrangements. Our research (Borgkvist et al. 2018), upon which this chapter is based, indicates that fathers do recognise changes in parenting expectations and express a desire to be more involved fathers. It is important, therefore, to examine how Australian men (and men in general) are negotiating these expectations and the support available to them. Furthermore, we need to determine how men who are using flexibility to engage in involved fathering are able to do so.

My research focused specifically on gender (masculinity) and how this might relate to the decisions that fathers make about using flexible working arrangements. Fifteen interviews were carried out with working fathers in which they were asked about how they managed their work and home lives, looking at what barriers and facilitators these fathers identified to flexibility use and how they talked about their decisions to use or not use flexibility. Their responses were then analysed with a gender lens.

A main finding from this research is that the ideal worker norm remains a significant barrier to fathers utilising flexible working arrangements. The construction of the ideal worker as dedicated to their jobs with no outside distractions and as able to work long hours was reinforced by organizational culture and was 
internalised by employees. While some fathers were using flexibility, such as coming in later after dropping kids off at school and a few who were working part-time, they were aware of a need to visibly minimise their time away from paid work. One father, for example, was doing school visits with his wife and child, but for the last visit had 'decided just to let them go to it' because he had taken too much time off. Another stated he did not 'want to be seen as someone who tries to get out of doing work,' and so he had decided not to approach his manager about using flexibility. Other participants of the research noted that within the organizational environment it was not considered unusual for women to use flexibility, though it was considered unusual for men. It seemed that the internalisation of these organizational expectations was an important aspect of men's decisions around flexibility; their value as organizational citizens is linked to productivity, and their identities being derived from this encouraged them to meet organizational expectations that they would be ideal workers (see also Tanquerel and Grau-Grau 2020).

Another factor identified as continuing to have an influence over men's decisions around the use of flexibility is the pervasive influence of masculinity. The interviewed fathers were more involved in care work than traditional masculinity would prescribe (Connell 2005b) and stated that they wanted to be involved in feeding, bathing, changing nappies, and other care-related activities. However, they positioned work as a more important aspect of their fathering identities. Fathers emphasised the importance and seniority of their positions at work and the resolve they had in overcoming difficulties in the workplace, firmly grounding their identities in paid work. One participant stated that if he worked part-time and his wife worked full-time, they would be better off financially, but he had worked hard to get to where he was 'so it would be absolutely silly to stop now and go part-time.' Participants also emphasised their roles as breadwinners and their female partners' roles as carers, with one participant stating that 'I can't imagine her going back to work and letting me look after the children when they were very young.' These kinds of statements were common, with participants tending to reinforce the gendered division of work and care in their interviews.

Though there were participants who were working part-time or using a formal form of flexibility so that they could be more involved in caregiving, they were not the majority. However, these men are of particular interest because they are stepping away from full-time paid work and creating a need to negotiate both their fathering identities and masculine identities. In this research, these men presented the most distinct attempt at a negotiation of an alternative masculine identity, one which more fully incorporated involved fathering. I termed these men 'ground-breakers.'

Of note, the 'ground-breaker' fathers were currently, or had previously been, working part-time, and they noted the difficulties they had faced in the workplace. One participant told of the assumption by his co-workers that he was still a full-time worker after he had been working part-time for over a year. He stated that he 'maybe was a little bit judged by some who had different attitudes towards men taking time off to do that' and that these 'were primarily people who had fairly strong ideas about what a male in a relationship or a father did, as opposed to what a mother did.' 
These 'ground-breaker' participants, though, inverted these difficulties. For example, they emphasised their psychological strength, spoke of themselves as having power and control over their behaviour, and of not caring what others thought of their choices. Another participant, Kieran, stated:

'For the most part it didn't bother me that much because I just thought, well, you know, maybe in some respects I might be a bit of a front runner in, you know, men being able to do this a bit more .... I wanted to do it. I wanted to spend time with my kids, and if other people thought badly of it or didn't do it themselves, ... it didn't bother me'.

Talking about being a 'front runner' and making things easier for other men, can be understood to reproduce traditional notions of masculinity. These participants described themselves as having strength, perseverance, and a sense of power in not caring what others thought of them and exercising agency. However, talking about their behaviour in relation to caretaking and part-time work which is usually associated with femininity provides an example of an alternative masculine identity. That is, fathers are stepping outside of the norm which presents the need for them to negotiate an identity which deviates from this norm. What a reliance on these traditional notions of masculinity also accomplishes, though, is similar to what has been found in research into how men who work in 'feminized' occupations negotiate masculine identity. Their emphasis on attributes which reaffirm masculinity allows them to distance themselves from femininity (Hrženjak 2013; Pullen and Simpson 2009).

Finally, fathers primarily talked about the use of flexibility, and particularly parental leave, as a privilege and a choice as opposed to a right. Taking time off for the birth of their children and using flexibility later on to assist in managing worklife conflict (Pocock 2005) was discussed as an individual choice and therefore their own responsibility to manage, rather than as something that should be supported by organizations and government policy. Fathers' accounts of leave-taking around the time of their children's birth was framed as a privilege, with one participant stating, 'I was very fortunate, probably 99 percent of the population don't get that opportunity.' Among these participants it seemed there was a distinct lack of 'sense of entitlement' (Lewis 1997) to time off and use of flexibility for family reasons. Fathers' lack of 'sense of entitlement' was further evidenced by their discussions of the normality of women using flexibility, and women's use of flexibility being framed as a right. However, as Lewis and Smithson (2001) noted, the type of welfare state that individuals experience has an influence on their expectations regarding support from both employer and state. As Australia is highly patriarchal and support for the breadwinner/carer dichotomy is apparent in both culture and social policy (Connell 2014), these participants' responses and general lack of 'sense of entitlement' to organizational support is in keeping with expected gender roles within the Australian social climate. 


\section{Implications and Recommendations}

What these results point to is that fathering expectations are changing in Australia and abroad, but there remains a strong connection between fathering identity and paid work which contributes to father's resistance to utilise flexibility for family reasons. Previous policy has also contributed to a gendered division of labour, and there is little policy support for men wanting to engage in shared or primary caring (Brennan 2011; Pocock et al. 2013). However, increasing men's use of flexibility will not come simply from policy change, particularly in the Australian climate. Other factors will be of relevance in encouraging a change in the way men work namely a cultural shift is required to motivate men, and fathers specifically, to challenge and reject traditional gender roles and attitudes. To work towards this, the barriers to men's ability to work in (what are currently considered) non-normative ways need to be tackled. Without adequate financial and cultural support for fathers to take periods of leave throughout children's lives, Australian families will continue to fall back on traditionally gendered patterns of work and care (Baxter 2013; Miller 2011).

Tackling cultural issues outside of workplaces will provide more insight in to how to break the link between masculinity and paid work that operates within them. Fathers may be encouraged to become aware of and challenge workplace structures which maintain gendered practices. Naming and challenging gendered stereotypes and processes, for example, has been found to have an impact on the ways in which male employees relate to male peers as well as to their families (Ely and Meyerson 2010). In particular, if it is considered that the men in my research did not appear to have a sense of entitlement to use flexibility, and that flexibility, like child-care, is still considered to be 'for women,' it makes sense that we see this reflected in lower numbers of Australian men using a formal form of flexible working arrangement. Changing broad Australian policy and encouraging organizations to change their own policies to provide more support, sends a message to men that their participation in child rearing and care taking activities is valued and valuable. Other countries have also found that the introduction of parental leave policy targeted at fathers has encouraged challenge and re-definition of ideas about what father's roles are, as well as underscoring the importance of father's involvement in the first year of the child's life. These policies have been successful in increasing men's short and longer term use of flexibility for family reasons (Brandth and Kvande 2009; Suwada 2017), and O'Brien (2013) suggested that a targeted policy initiative can be successful even in countries with a strong breadwinner ideology.

Brandth and Kvande (2009) also discuss the need to filter out policies which are presented as gender neutral. They showed that these policies do not challenge gender inequality because it is usually the mother who ends up utilising them. This is true of the current PPL scheme in Australia and of many flexibility policies within organizations (Ahmed 2007). The effect of this is that flexibility is still implicitly considered to be 'for women' within organizations (see also Borgkvist et al. 2021). Making this visible is something which needs to occur to allow fathers to feel an entitlement to use flexible working arrangements. 
Our research, like other research from around the world, has identified that many fathers remain reluctant to use flexibility, with numerous barriers to this use being cultural and gendered in nature. Scandinavian countries have demonstrated that culture change is vital, and changes in social norms and expectations can be facilitated by government policy. Therefore, I suggest that tangible and practical policy change in Australia will play a key role in encouraging more fathers to use flexible working arrangements and parental leave. Evidence-based research tells us that when fathers are provided with well-compensated, targeted, and extended parental leave, they are very likely to take it (Brandth and Kvande 2009; O'Brien 2013; Wall 2014). This is an important consideration given that when fathers are involved early on in an infant's life, they are more likely to maintain that involvement as the child grows and throughout the child's life (Huerta et al. 2013; Miller 2017).

As a country, there is a need to show fathers that their involvement is valuable and that time off from paid work for family reasons is a workplace benefit that should be used by all. This needs to start with more inclusive and supportive policy. I conclude with some suggestions for policy makers, organizations, and fathers in Australia:

- Policy makers should implement a specified period of paid parental leave for fathers

- Policy makers should consider quotas for the use of flexible working arrangements by male employees within mid-large size organizations

- Organizations should maintain transparency with all employees regarding flexible and paid parental leave policies

- Organizations should consider a top down approach to culture change, such that senior managers model and support flexible working arrangements

- Fathers should be willing to challenge organizational and cultural norms, and request support from their managers to balance work and family responsibilities

Acknowledgements This research was conducted as part of my $\mathrm{PhD}$ program at the University of Adelaide, South Australia. I would like to extend my gratitude to my $\mathrm{PhD}$ supervisors, to Dr. Elizabeth Hoon who read and provided feedback on an earlier version of this chapter, and to the editors and reviewers for their supportive feedback.

\section{References}

Acker J (1990) Hierarchies, jobs, bodies: a theory of gendered organizations. Gend Soc 4 (2):139-158

Ahmed S (2007) The language of diversity. Ethn Racial Stud 30(2):235-256

Baxter J (2013) Parents working out work. In: Australian Family Trends. No. 1. Australian Institute of Family Studies, Melbourne. https://aifs.gov.au/publications/archived/864

Baxter J, Hewitt B (2013) Negotiating domestic labor: Women's earnings and housework time in Australia. Fem Econ 19(1):29-53 
Baxter JA, Smart D (2011) Fathering in Australia among couple families with young children. In: Family Matters No. 88. Australian Department of Families, Housing, Community Services and Indigenous Affairs, Melbourne. https://aifs.gov.au/sites/default/files/fm88b.pdf

Borgkvist A, Eliott J, Crabb S, Moore V (2018) 'Unfortunately I'm a massively heavy Sleeper': an analysis of fathers' constructions of parenting. Men and Masculinities. https://doi.org/10.1177/ $1097184 x 18809206$

Borgkvist A, Moore V, Eliott J, Crabb S (2018) 'I might be a bit of a front runner': an analysis of Men's uptake of flexible work arrangements and masculine identity. Gend Work Organ 25 (6):703-717

Borgkvist A, Moore V, Crabb S, Eliott J (2021) Critical considerations of workplace flexibility "for all" and gendered outcomes: men being flexible about their flexibility. Gend Work Organ. https://doi.org/10.1111/gwao.12680

Brandth B, Kvande E (1998) Masculinity and child care: the reconstruction of fathering. Sociol Rev 46(2):293-313

Brandth B, Kvande E (2002) Reflexive fathers: negotiating parental leave and working life. Gend Work Organ 9(2):186-203

Brandth B, Kvande E (2009) Gendered or gender-neutral care politics for fathers? Annals of the American Academy of Political and Social Science 624(1):177-189

Brandth B, Kvande E (2018) Masculinity and fathering alone during parental leave. Men Masculinities 21(1):72-90. https://doi.org/10.1177/1097184x16652659

Brennan D (2011) Australia: the difficult birth of paid maternity leave. In: Kamerman SB, Moss P (eds) The politics of parental leave policies: children, parenting, gender and the labour market. The Policy Press, Bristol, pp 15-32

Charlesworth S, Heron A (2012) New Australian working time minimum standards: reproducing the same old gendered architecture? J Ind Relat 54(2):164-181. https://doi.org/10.1177/ 0022185612437840

Coltrane S, Miller EC, DeHaan T, Stewart L (2013) Fathers and the flexibility stigma. J Soc Issues 69(2):279-302. https://doi.org/10.1111/josi.12015

Connell RW (2005a) A really good husband: work/life balance, gender equity and social change. Aust J Soc Issues 40(3):369-383

Connell RW (2005b) Masculinities. Allen \& Unwin, Crows Nest

Connell RW (2014) Feminist scholarship and the public realm in postcolonial Australia. Aust Fem Stud 29(80):215-230

Cooper M (2000) Being the "go-to guy": fatherhood, masculinity, and the Organization of Work in Silicon Valley. Qual Sociol 23(4):379-405

Correll S, Kelly E, O'Connor LT, Williams J (2014) Redesigning, redefining work. Work Occup 41 (1):3-17

Craig L, Mullan K (2010) Parenthood, gender and work-family time in the United States, Australia, Italy, France, and Denmark. J Marriage Fam 72(5):1344-1361

Dolan A, Coe C (2011) Men, masculine identities and childbirth. Sociol Health Illn 33 (7):1019-1034. https://doi.org/10.1111/j.1467-9566.2011.01349.x

Dyrenfurth N (2015) Mateship: a very Australian history. Scribe Publications, Australia

Edley N, Wetherell M (1999) Imagined futures: young Men's talk about fatherhood and domestic life. Br J Soc Psychol 38(2):181-194. https://doi.org/10.1348/014466699164112

Ely R, Meyerson D (2010) An organizational approach to undoing gender: the unlikely case of offshore oil platforms. Res Organ Behav 30(C):3-34. https://doi.org/10.1016/j.riob.2010.09. 002

Gray E (2013) Fatherhood and Men's involvement in paid work in Australia. In: Baxter AEAJ (ed) Negotiating the life course: stability and change in life pathways. Springer Science and Business Media, Dordrecht, pp 161-174

Halford S (2006) Collapsing the boundaries? Fatherhood, organization and home-working. Gend Work Organ 13(4): 383-402. doi:10.1111j.1468-0432.2006.00313.X 
Harrington B, Van Deusen F, Ladge J (2010) The new dad: exploring fatherhood within a career context. Boston College Center for Work \& Family, Boston

Hrženjak M (2013) Negotiating masculinity in informal paid care work. Int Rev Sociol 23 (2):346-362. https://doi.org/10.1080/03906701.2013.804296

Huerta M d C, Adema W, Baxter J, Han W-J, Lausten M, Lee RH, Waldfogel J (2013) Fathers' leave, Fathers' involvement and child development: are they related? Evidence from four OECD countries. In: OECD Social, Employment and Migration Working Papers, No. 140. OECD Publishing, New York. https://doi.org/10.1787/5k4dlw9w6czq-en

Kelly EL, Ammons SK, Chermack K, Moen P (2010) Gendered challenge, gendered response. Gend Soc 24(3):281-303. https://doi.org/10.1177/0891243210372073

Lewis S (1997) 'Family Friendly' employment policies: a route to changing organizational culture or playing about the margins? Gend Work Organ 4(1):13-23

Lewis S, Smithson J (2001) Sense of entitlement to support for the reconciliation of employment and family life. Hum Relat 54(11):1455-1481. https://doi.org/10.1177/00187267015411003

Miller T (2011) Falling Back into gender? Men's narratives and practices around first-time fatherhood. Sociology 45(6):1094-1109. https://doi.org/10.1177/0038038511419180

Miller T (2017) Making sense of parenthood: caring, gender and family lives. Cambridge University Press, Cambridge

Miller T, Nash M (2016) 'I just think something like the "bubs and pubs" class is what men should be having': paternal subjectivities and preparing for first-time fatherhood in Australia and the United Kingdom. J Sociol 53(3):541-556. https://doi.org/10.1177/1440783316667638

Murrie L (1998) The Australian legend: writing Australian masculinity/writing 'Australian' masculine. Journal of Australian Studies 22(56):68-77

O'Brien M (2013) Fitting fathers into work-family policies: international challenges in turbulent times. Int J Sociol Soc Policy 33(9/10):542-564

O'Brien M, Brandth B, Kvande E (2007) Fathers, work and family life. Community, Work and Family 10(4):375-386

OECD (2016) Parental leave: where are the fathers? Men's uptake of parental leave is rising but still low. https://www.oecd.org/policy-briefs/parental-leave-where-are-the-fathers.pdf

Pedulla D, Thébaud S (2015) Can we finish the revolution? Gender, work-family ideals, and institutional constraint. Am Sociol Rev 80(1):116-139. https://doi.org/10.1177/ 0003122414564008

Pocock B (2005) Work-life 'Balance' in Australia: limited Progress, dim prospects. Asia Pac J Hum Resour 43(2):198-209. https://doi.org/10.1177/1038411105055058

Pocock B, Charlesworth S, Chapman J (2013) Work-family and work-life pressures in Australia: advancing gender equality in "good times"? Int J Sociol Soc Policy 33(9/10):594-612

Pullen A, Simpson R (2009) 'Managing difference in feminized Work': men, otherness, and social practice. Hum Relat 62(4):561-587

Riggs D, Bartholomaeus C (2018) 'That's my job': accounting for division of labour amongst heterosexual first time parents. Community Work Fam 23(1):107-122. https://doi.org/10.1080/ 13668803.2018.1462763

Rose J, Brady M, Yerkes MA, Coles L (2015) 'Sometimes they just want to cry for their mum': Couples' negotiations and Rationalisations of gendered divisions in infant care. J Fam Stud 21 (1):38-56. https://doi.org/10.1080/13229400.2015.1010264

Shirani F, Henwood K, Coltart C (2012) Why Aren't you at work?: Negotiating economic models of fathering identity. Fathering 10(3):274-290

Singleton A, Maher J (2004) The "new man" is in the house: young men, social change, and housework. J Men Stud 12(3):227-240. https://doi.org/10.3149/jms.1203.227

Summers A (1975) Damned whores and God's police: the colonization of women in Australia. Penguin Books, Ringwood 
Suwada K (2017) Men, fathering and the gender trap: Sweden and Poland compared. Palgrave Macmillan, Cham

Tanquerel S, Grau-Grau M (2020) Unmasking work-family balance barriers and strategies among working fathers in the workplace. Organization 27(5), 680-700. https://doi.org/10.1177/ 1350508419838692

Wall K (2014) Fathers on leave alone: does it make a difference to their lives? Fathering 12 (2):196-210. https://doi.org/10.3149/fth.1202.196

Williams JC (2010) Reshaping the work-family debate: why men and class matter. Harvard University Press, Cambridge

Open Access This chapter is licensed under the terms of the Creative Commons Attribution 4.0 International License (http://creativecommons.org/licenses/by/4.0/), which permits use, sharing, adaptation, distribution and reproduction in any medium or format, as long as you give appropriate credit to the original author(s) and the source, provide a link to the Creative Commons license and indicate if changes were made.

The images or other third party material in this chapter are included in the chapter's Creative Commons license, unless indicated otherwise in a credit line to the material. If material is not included in the chapter's Creative Commons license and your intended use is not permitted by statutory regulation or exceeds the permitted use, you will need to obtain permission directly from the copyright holder. 